\title{
Industrial Policy for the Machine Tool Industries of South Korea and Taiwan
}

\author{
Staffan Jacobsson
}

The machine tool industry, though a very small part of the metal-working industry ${ }^{2}$ in all countries, is nevertheless generally regarded as strategic: it produces the machines to make all other machines. This 'spider in the web' position of the machine tool industry has led many economic theorists and planners to give it central importance [eg Feldman 1965; Mahalanobis 1955/56; Raj and Sen 1961; Cooper 1983]. ${ }^{3}$

This article discusses how industrial policy in South Korea (hereafter Korea) and Taiwan is helping the machine tool producing firms to improve their technological capabilities and move into the production of computer numerically controlled machine tools. The next section contains a brief outline of the character of technical change in the industry globally, and shows how the nature of competition has been changing. Then follows an outline of the main characteristics of the machine tool industries in Korea and Taiwan, and how the government historically fostered the industry. Finally, we discuss the appropriateness of present government policies for fostering further advance of the machine tool industries.

\section{Technical Change and the Nature of Competition in the Industry}

The machine tool industry has been undergoing rapid technical change, and associated with this change there has been an alteration in the nature of

\footnotetext{
1 This article is part of a larger research project on the production of numerically controlled lathes in Argentina. Taiwan and Korea. The project is financed by the Swedish Agency for Research Cooperation with the Developing Countries whose assistance is gratefully acknowledged. Fieldwork was undertaken in Taiwan and Korea for three weeks each in 1983.

2 Defined as those industries covered by International Standard Industrial Classification (ISIC) 38.

3 For a review of this debate see Brundenius [1984]. Rosenberg [1976] and Jones [1983] both emphasise the role of the machine tool industry as a diffuser of new technology throughout the engineering industry.
}

competition in the industry. The technical change originates outside the machine tool industry, in the electronics industry. The influence of the electronics industry is manifested by a substitution of conventional machine tools by computer numerically controlled (henceforth $\mathrm{CNC}$ ) machine tools.

The first machine tool controlled by a numerical control unit was produced in the $1950 \mathrm{~s}$, but the diffusion of this new technology began to be significant only after 1970 when the first mini computer-based CNC unit was developed. Since 1975, when the first micro-computer-based CNC unit was developed, the diffusion has become very rapid indeed, and by 1981 , around 40 per cent of the investment in metal cutting machine tools was made in CNC machine tools in Japan, the US and in Sweden. The ratio had increased to nearly 46 per cent in Japan by 1982 .

Among the metal cutting machine tools, lathes are feeling the greatest impact from the electronics industry. In Sweden in 1981, 78 per cent of the invest ment in lathes was accounted for by $\mathrm{CNC}$ lathes whilst the average in the main OECD countries amounted to around 50 per cent. It is noteworthy that the lathe is also the single most important machine tool produced in both Korea and Taiwan. In Korea in 1982,47 per cent (in value terms) of the metal cutting machine tools produced were lathes whilst 74 per cent of exports were lathes. In Taiwan, 38 per cent of the value of exports of machine tools in 1981 consisted of lathes.

Associated with the change in the product technology of at least some machine tools, the nature of competition in the global machine tool industry has altered. Traditionally the machine tool producing firm is a small firm, the industry being very atomised. For example, the medium plant size in Germany and the US is just over 400 employees [Jones 1983]. In Taiwan, a number of very small firms exist and profitably 
produce conventional machine tools. For example, one firm which produces engine lathes, the simpler type of lathe, employs only 150 people.

However, for those firms producing metal-cutting machine tools, and mainly lathes, milling, drilling and boring machines, major changes are taking place as regards the structure of the industry in which they operate. Size is becoming a much more important factor than it used to be, as illustrated by data on the Japanese CNC lathe industry. The five leading firms produced 60 per cent of the total Japanese production of CNC lathes in 1975. This share grew to 76 per cent in 1981. The average output of these firms in terms of units of CNC lathes was approximately 160 in 1975. This grew to 1,600 in 1981 . In terms of value, the average output of CNC lathes grew from US $\$ 7.9 \mathrm{~m}$ in 1975 to US $\$ 110 \mathrm{~m}$ in 1981 in current prices [Chudnovsky et al 1983].

The large size of the firms reflects the very substantial economies of scale that can be reaped not only in the production of $\mathrm{CNC}$ lathes but also in the production of machining centres. A machining centre is a computer controlled machine tool which combines milling, drilling and boring capabilities. Together with $\mathrm{CNC}$ lathes, machining centres account for the bulk of the CNC machine tools produced. The size of the machine tool firms producing CNC machine tools also reflects the growth in the need for design capabilities in order to be able to keep up in the ever faster rate of technical change. Whilst the Taiwanese firm mentioned above survives in the market for conventional lathes with five design engineers, firms attempting to compete internationally in the $\mathrm{CNC}$ lathe field need 10 or even 20 times the number of design engineers. Some Japanese firms even employ several hundred design engineers.

\section{The Machine Tool Industries of Taiwan and Korea}

The origin of the Taiwanese machine tool industry is fairly recent. After the Second World War the development of the industry was retarded by the small size of the local market as well as by the low technical level of its customers [Amsden 1977]. However, towards the middle or end of the 1960s, the industry began to grow in response to both greater local capital accumulation and, especially, to growing regional demand resulting particularly from the Vietnam war. The Taiwanese machine tool industry took advantage of the demand for low quality and low performance machine tools by very price sensitive customers.

The industry became export oriented at an early stage, and by 1968 had achieved a 50 per cent export share. The exports were mainly for the regional market initially, but in the mid 1970s, the main market for the
Taiwanese machine tool industry became the USA. In 1981 , over 77 per cent of exports went to developed countries. Indeed, Taiwan is the fourth largest exporter of machine tools to the US. By 1977 Taiwan became a net exporter of machine tools, the first newly industrialising country (NIC) to reach this position. The export orientation (in 1981 Taiwan exported 73 per cent of production) was conducive to a very rapid growth in the production of machine toois. The value of production rose from US $\$ 22 \mathrm{mn}$ in 1973 to US $\$ 242 \mathrm{mn}$ in 1981 . Although the export market shifted to the developed countries, the strategy of focusing on the more sensitive segments of the market continued.

By all standards the Taiwanese machine tool industry has been very successful. The perhaps surprising conclusion reached when studying the role of government policy is that there has been very little directed governmental influence on the industry. The nominal tariff rate has been very low, around 10 per cent, and the effective tariff has been about the same. Some subtle import controls on machine tools exist, but are almost certainly less stringent than Korea's. On the whole, the growth in the capability of Taiwan's machine tool industry has occurred gradually and 'autonomously' from an initial choice of pro$\mathrm{duct} / \mathrm{market} \mathrm{mix}$ with low barriers to entry. The indirect influence of government policy on this process has probably been greater than its direct influence. Of particular importance to the export success has been the stability in the real exchange rate, ensuring stable relative prices of foreign and domestically made goods. This stability has, of course, had the effect of reducing the risks involved in investing in a marketing network abroad, and has allowed the entrepreneurs to base their strategies on expansion in foreign markets. Finally, the domestic demand for machine tools has been constantly growing and has not, in contrast to many other economies, fluctuated greatly.

As in the case of Taiwan, the Korean machine tool industry originated in the period after the Second World War. The industry remained very small, however, until the mid $1970 \mathrm{~s}$. In terms of value of production it was only marginally smaller than Taiwan's, but Korea's GNP is far larger than Taiwan's. Furthermore, the export ratio was very low (only 12 per cent in 1974). In the second half of the 1970 s the Korean machine tool industry went through a period of explosive growth. Production rose from US $\$ 13 \mathrm{mn}$ in 1973 to US $\$ 178 \mathrm{mn}$ in 1981 (Table 1). Exports failed, however, to rise to a level comparable with Taiwan; only 18 per cent was exported in 1981 . The fast growth in the production of machine tools was instead based on a very rapidly growing home market. By 1979, Korea had become the tenth largest investor in machine tools in the world. The Korean 
expansion of machine tool production has a large element of import substitution; the import share of machine tool investment declined from 73 per cent in 1974 to 39 per cent in 1981. In contrast, Taiwan's import share is around 60 per cent - a difference related to the fact that in Taiwan it is a government agency which decides whether to allow imports or not, while in Korea it is the machine tool makers association itself that has the delegated power to decide. Unlike Taiwan, Korea is still, however, a net importer of machine tools. In 1981 the trade deficit amounted to around $\$ 100 \mathrm{~m}$, a figure which can be compared to the total investment in machine tools in the same year of $\$ 331.3 \mathrm{mn}$.

\section{Table 1}

Production of machine tools in the Republic of Korea and Taiwan 1971-81, selected years

(in US\$ mn)

\begin{tabular}{lrc}
\hline & Korea & Taiwan \\
\hline 1971 & 5.2 & 12.8 \\
1973 & 12.6 & 22.0 \\
1977 & 73.7 & 67.8 \\
1979 & 163.7 & 189.1 \\
1981 & 178.0 & 242.3 \\
\hline
\end{tabular}

Sources: - Taiwan's Machine Tool Manufacturers' Association - Korea: 1971-77: Economic Planning Board: Report on Mining and Manufacturing Survey (various). Machine tools are here defined as KSIC 38231 and 38232. For 1979 and 1981: American Machinist, February 1981 and February 1983.

Apart from the rapid growth in domestic demand, which indeed was a function of the Korean government's major effort to build up a machine tool industry in Korea, the Korean Government has, unlike its Taiwanese counterpart, played a major role in the development of its machine tool industry [Bendix et al 1978]. The central features of its policies were:

- the availability of long term loans with subsidised interest rates;

- import prohibitions on items which could be produced locally;

- financial assistance to Korean machinery firms who bought Korean-made machine tools.

A condition, or possibly a preference, was, however, that the firms receiving such incentives should export a certain proportion of their output.

The government interest in the machine tool industry was further underlined in the 1981 Basic Plan for the Advancement of the Machinery Industry. The instru- ments used by the government are again import restrictions and credit policies. Thus, the Korean Government has shown itself to be ready to intervene greatly in the industry. The import substitution character of the development of the machine tool industry also clearly suggests that the government has been influential in its policies.

\section{Government Policy and the Entry into Production of CNC Machine Tools}

Taiwan and the Republic of Korea have entered into the production of both CNC lathes and machining centres (Table 2). Both countries are far ahead of other semi-industrialised countries in this field [Chudnovsky et al 1983]. While Taiwan entered earlier than Korea, Korea has now overtaken Taiwan in the production of both CNC lathes and machining centres. In terms of value, Korean production of these two types of machine tools amounted to US\$16.5mn in 1982 against Taiwanese production of only US $\$ 9 \mathrm{mn}$.

Korea has thus overtaken Taiwan, in spite of the latter country's earlier start. However, in terms of the requirements set by the international nature of competition, all firms in both countries produce below the minimum efficient scale of production. As mentioned earlier, scale is now very important and indeed, only one out of eight firms interviewed in these countries claimed that they made a profit on the production of $\mathrm{CNC}$ lathes. In both countries the machine tool industry is very atomised. In Korea 17 firms produce lathes; in Taiwan, 30. (Total lathe production in Taiwan is however larger than Korea's.) Of this population, three firms in Korea and two or three firms in Taiwan have emerged as leaders on the basis of scale of output and 'mass' of technological capabilities. These five or six firms produce nearly all of the CNC machine tools in these countries. These firms all have sales of between US $\$ 10$ and US $\$ 20 \mathrm{mn}$ and have a design staff of between 30 and 60 engineers. Other firms producing conventional machine tools survive only in a much smaller form.

Although most of these firms are not yet competitive on the world market for CNC machine tools, they are the only ones to have a reasonable chance of being able to become successful in the light of the requirements set by the international industry. To the extent that we accept the argument of the strategic nature of the machine tool industry, it is of interest to the rest of the society that these firms do make it. Given that the objective function of the government includes a healthy domestic machine tool industry, the question arises as to whether the government needs to intervene in the market and if so, how? 


\begin{tabular}{lcc|cl}
\hline \multicolumn{2}{c|}{ Taiwan } & \multicolumn{2}{c}{ Korea } \\
\hline year & CNC lathes & machining centres & CNC lathes & machining centres \\
\hline 1977 & 14 & - & - & \\
1978 & 40 & - & - & not available but \\
1979 & 78 & 7 & 9 & probably zero \\
1980 & 106 & 24 & 87 & 75 \\
1981 & 174 & 18 & 222 & \\
1982 & 163 & 53 & & \\
\hline
\end{tabular}

Source: - Taiwan: Industrial Technology Research Institute for 1977-82 in the case of machining centres. The same source was used for CNC lathes except for 1982 which is author's own survey.

- Korea: for 1982, Ministry of Commerce and Industry. For other years, data are the production data of the leading producer of $\mathrm{CNC}$ lathes in Korea. 1981 production may be a slight underestimate.

Although the argument about the central role of the machine tool industry bases itself mainly on the existence of external economies, which according to conventional economics would be a reason in favour of intervention, the main arguments in favour of such an intervention are the non marginal changes in the nature of competition in the industry. For these firms, the question is not to advance gradually to a marginally stronger position in terms of skills and financial strength, but rather to implement radical changes. Design personnel and sales often need to be doubled at least, and the marketing network needs to be strengthened, as does production capacity. Large investments therefore need to be undertaken, and as such investments normally involve a radical change in strategy the uncertainties and risks are perceived by the firms to be great. A call for government intervention is therefore justified on account of what economists call 'imperfections' in the capital market.

Both Taiwan and Korea have designed specific policies for the machine tool industry. Whilst the Korean policy has been in operation for some time, the Taiwanese one was initiated as late as 1982 . The two main elements are trade restrictions and credit policies.

In February 1983, the Taiwanese Government was at least contemplating a rise in the tariff rate to 20 per cent for some more advanced machine tools, including CNC machine tools. The Korean Government allows import restrictions to be applied for machine tools which can be produced domestically. The noteworthy aspect of this policy is that it is the Machine Tool Manufacturers Association which in reality decides which machine tools can be produced locally, and therefore those which can be imported. In the case of CNC lathes in Korea, the present rule is that all CNC lathes below a certain size must be supplied from domestic sources. As the size limit is larger, the vast majority of CNC lathes cannot be imported. ${ }^{4} \mathrm{It}$ is also the case that the import share of investment in CNC lathes dropped from 85 per cent in 1981 to 31 per cent in 1982 in value terms.

Import restrictions, be they quantitative restrictions or tariffs, are general policy instruments. Thus, as long as a firm sells a CNC machine tool on the local market it may be favoured by this policy. This also means that the firms which in the long run do not stand a reasonable chance of succeeding in this business will be favoured. As all instruments of this kind are associated with a cost to the consumer, resources will be applied in an inefficient way as a consequence of the general character of the instrument. Import restrictions are, however, much more inappropriate from another point of view. The strategic nature of the machine tool industry has been partly attributed to its role as the diffuser of new innovations, as discussed above. With the application of import restrictions, the domestic users of machine tools will be prevented from benefitting from this role of the international machine tool industry.

\footnotetext{
4 This point was understood in an interview conducted within the framework of a project carried out with Dr Charles Edquist on the 'Patterns of specialisation within the capital goods sectors of India and the Republic of Korea".
} 
Of course, to the extent that the domestic supplying industry can produce the same range of $\mathrm{CNC}$ machine tools as are supplied by the international industry, at a price equal to the international price, the domestic buyers of machine tools would not suffer. However, leaving price differences aside, a fundamental feature of the machine tool industry is the high degree of product differentiation, which extends even to such a well-defined product as CNC lathes. In the case of $\mathrm{CNC}$ lathes the domestic industry in Korea produces only low performance machinery. In the OECD countries, the buyers of such machine tools are generally very price sensitive small firms. However, in Korea, where import restrictions apply to all CNC lathes below a certain size, all machine tool buyers will have to settle for the low performance Korean CNC lathes.

The benefits accruing to the machine tool producers from import restrictions on machine tools would arise from having the home market to exploit and thereby reaching a greater volume of production and thus gaining from scale economies. However, the domestic market in both these countries is so small in relation to the minimum efficient scale of production that it can be of only marginal use to local machine tool builders [Chudnovsky et al 1983]. The very limited size of the domestic market is also recognised by the firms, all of whom regard the US market as their home market for CNC machine tools. Thus, import restrictions in this case are not only inefficient but also imply that local users of machine tools will get less access to the new international technology embodied in machine tools.

The other main component in government policies concerns credit. In Korea, the state channelled large amounts of capital into the machinery industry in the second half of the 1970s. The machine tool industry also received credits with negative real interest rates. Furthermore, some firms received subsidies because they moved to the Changwon industrial complex in the south of Korea in 1976-78. The most dramatic case of government intervention is the build-up of the now largest producer of $\mathrm{CNC}$ lathes in Korea, and indeed in the NICs. This firm, which is part of a larger conglomerate, started from scratch in 1977 with a loan of over US $\$ 40 \mathrm{mn}$. Other firms also received credits, but not on the same scale.

In Taiwan, the government implemented a Strategic Industry Programme in 1982. The programme has approximately US $\$ 250 \mathrm{mn}$ at its disposal and the money is allocated to individual firms for the production of about 115 types of product. It can be used to finance up to 65 per cent of the costs of a new project, including skill formation. The explicit purpose of the fund is to absorb some of the risks associated with the initiation of new and more advanced product lines. The second largest $\mathrm{CNC}$ machine tool producer in Taiwan is one of the firms which receive funding from this programme. The firm is building a new plant for the production of a large number of CNC machine tools using very advanced production technology. Money is also available for the other leading firms as and when they wish to use it.

Hence, in terms of the credit policies, both governments have shown a willingness to design policies which assist the leading firms in the machine tool industry to enter or consolidate an entry into the market for CNC machine tools. The magnitude of the intervention is however different. Whilst complete data are not available, the Korean intervention is much greater than the Taiwanese. In part, this stems from the different needs of the industry, the Korean machine tool industry being younger than the Taiwanese. In part, however, the difference reflects greater overall state involvement in Korea than in Taiwan, an involvement which has contributed to the Korean industry overtaking the Taiwanese in the CNC machine tool field.

Of course, in social cost benefit terms this does not necessarily imply that the Koreans are better off, as the cost of the intervention has been high. In conjunction with the non marginal changes in the nature of competition in the industry, the tremendous growth in strength of the Korean industry may suggest however that Taiwan may like to reconsider its present comparatively marginal intervention.

Such a change in thinking would need to apply to credit policy, which should be extended if the leading firms want to initiate more radical changes in strategy and compete directly with Japanese firms. The possibility of restructuring the remaining part of this atomised industry in order to increase the technological and financial capabilities of the firms ought also to be an area of concern. There is, however, a Chinese proverb which says: 'Better the head of the chicken than the tail of a cow' [Fransman 1983]. In other words, firms will not voluntarily merge, or even collaborate. It is typical that the six firms which produce CNC lathes in Taiwan do not collaborate in the purchase of components, nor in marketing - both functions where there can be large economies of scale. The leading firms would not necessarily need to merge or collaborate, even though obvious benefits could arise, but for the mass of small firms this would be a prerequisite for possible future entry into CNC machine tool production. The alternative in the long run would be to face increasing competition in the world market for conventional machine tools. 


\section{References}

Amsden, A., 'The division of labour is limited by the type of market: the case of Taiwanese machine tool industry', World Development, vol 5 no 3, pp 217-33

Bendix, P. J., C. Kim, M. Korner, U. Kloos, K. Schneider and P. Wolff, 1978, Development and Perspectives of the Korean Machinery Industry - with special reference to machine tool, electrical machinery and plant equipment manufacturing, German Development Institute

Brundenius, C., 1984, Capital Goods in Economic Thought. Some Notes from Selected Readings, Research Policy Institute, University of Lund

Chudnovsky, D., M. Nagao and S. Jacobsson, 1983, Capital Goods Production in the Third World: an economic study of technology acquisition, Frances Pinter, London

Cooper, C., 1983, 'Extensions of the Raj-Sen model of economic growth', Oxford Economic Papers 35

Feldman, G. A., 1965, 'On the theory of growth rates of national economy' in N. Spulber (ed), Formulations of Soviet Strategy for Economic Growth, Bloomington
Fransman, M., 1983, 'Some notes on machine tool production in Taiwan', Dept of Economics, University of Edinburgh, mimeo

Jacobsson, S., 1983, 'Numerically controlled machine tools - implications for newly industrialised countries' in S. Jacobsson and J. Sigurdson (eds), Technological Trends and Challenges in Electronics, Research Policy Institute, University of Lund

Jones, D., 1983, 'Machine tools: technical change and a Japanese challenge', Science Policy Research Unit, University of Sussex, mimeo

Mahalanobis, P. C., 1955/56, "The approach to operational research and planning in India', Sankhya, The India Journal of Statistics, 16

Raj, K. N. and A. K. Sen., 1961, 'Alternative patterns of growth under conditions of stagnant export earnings', Oxford Economic Papers, February

Rosenberg, N., 1976, Perspectives on Technology, Cambridge University Press 